\title{
A Critical Role for Macrophages Near Axotomized Neuronal Cell Bodies in Stimulating Nerve Regeneration
}

\author{
Jon P. Niemi, ${ }^{1}$ Alicia DeFrancesco-Lisowitz, ${ }^{1}$ Lilinete Roldán-Hernández, ${ }^{1,2}$ Jane A. Lindborg, ${ }^{1}$ Daniel Mandell, ${ }^{1}$ \\ and Richard E. Zigmond ${ }^{1}$ \\ Departments of ${ }^{1}$ Neurosciences and ${ }^{2}$ Graduate Studies, Case Western Reserve University, Cleveland, Ohio 44106-4975
}

\begin{abstract}
Macrophages have been implicated in peripheral nerve regeneration for some time, supposedly through their involvement in Wallerian degeneration, the process by which the distal nerve degenerates after axotomy and is cleared by phagocytosis. Thus, in several studies in which macrophage accumulation in the distal nerve was reduced and Wallerian degeneration inhibited, regeneration was delayed. However, this interpretation ignores the more recent findings that macrophages also accumulate around axotomized cell bodies. The function of macrophage action at this second site has not been clear. In two mutant strains of mice, the slow Wallerian degeneration $\left(W l d^{s}\right)$ mouse and the chemokine receptor CCR2 knock-out mouse, we report that macrophage accumulation after axotomy was abolished in both the dorsal root ganglion (DRG) and the distal sciatic nerve. To measure neurite outgrowth, DRG neurons were given a conditioning lesion, and outgrowth was measured in vitro $7 \mathrm{~d}$ later in the absence of the distal nerve segment. The increased growth normally seen after a conditioning lesion did not occur or was reduced in $W l d^{s}$ or $C C R 2^{-/-}$mice. In the superior cervical ganglion (SCG), particularly in $W l d^{s}$ mice, macrophage accumulation was reduced but not abolished after axotomy. In SCG neurons from Wld mice, the conditioning lesion response was unchanged; however, in $C C R 2^{-/-}$mice in which the effect on macrophage accumulation was greater, SCG neurite outgrowth was significantly reduced. These results indicate that macrophages affect neurite outgrowth by acting at the level of peripheral ganglia in addition to any effects they might produce by facilitation of Wallerian degeneration.
\end{abstract}

\section{Introduction}

In the peripheral nervous system unlike in the CNS, the axon segment distal to a lesion degenerates rapidly (Wallerian degeneration), and the proximal segment regenerates. Both degeneration and regeneration involve the interaction of axons with nonneuronal cells, including macrophages and Schwann cells. Wallerian degeneration begins rapidly after axonal damage and was thought to result from general blockade of axonal transport (Joseph, 1973); however, this simple view changed with the discovery of the slow Wallerian degeneration $\left(W l d^{s}\right)$ mouse in which degeneration takes weeks to begin (Lunn et al., 1989).

Early studies on the role of macrophages in Wallerian degeneration, reviewed by Perry (1994), include observations by Ramon y Cajal that blood-borne cells play a role in clearing myelin. Although peripheral nerves, like other tissues, contain "resident"

\footnotetext{
Received July 12, 2012; revised Aug. 29, 2013; accepted Sept. 3, 2013.

Author contributions: J.P.N. and R.E.Z. designed research; J.P.N., A.D.-L., L.R.-H., J.A.L., and D.M. performed research; J.P.N., A.D.-L., J.A.L., D.M., and R.E.Z. analyzed data; R.E.Z. wrote the paper.

This research was supported by National Institutes of Health Grants DK097223, NS017512, P30EY11373, and GM075207 (L.R.-H.) and Training Grant NS067431 (J.P.N., J.A.N.). We thank Heather Butler and Kathryn Franke for maintaining the WId and $C C R 2^{-/-}$breeding colonies, Anna Yakubenko for genotyping the mutant animals, Maryanne Pendergast for advice on imaging, and Jared Cregg for helpful comments on this manuscript. We also thank Dr. Jeff Milbrandt (Washington University, St. Louis, MO) and Dr. Timothy Kern (Case Western Reserve University, Cleveland, $\mathrm{OH})$ for providing our original breeding pairs of the $W I d^{5}$ and the $C\left(R 2^{-/-}\right.$mice, respectively.

The authors declare no competing financial interests.

Correspondence should be addressed to Richard E. Zigmond, Case Western Reserve University, Department of Neurosciences, 10900 Euclid Avenue, Cleveland 0H 44106-4975. E-mail: rez@case.edu.

DOI:10.1523/JNEUROSCI.3319-12.2013

Copyright $\odot 2013$ the authors $\quad 0270-6474 / 13 / 3316236-13 \$ 15.00 / 0$
}

macrophages (Oldfors, 1980), primarily "infiltrating" monocytes have been implicated in Wallerian degeneration (Beuche and Friede, 1984; Lunn et al., 1989), and the slow Wallerian degeneration in the $W l d^{s}$ mouse is accompanied by delayed monocyte influx (Lunn et al., 1989; Hall, 1993).

The idea that macrophages also play a role in nerve regeneration and do so by their effects on Wallerian degeneration has been based on two arguments. First, blockade of macrophage accumulation in the distal nerve and the resulting slow Wallerian degeneration have been shown to be associated in several studies with slow nerve regeneration (Brown et al., 1991b; Dailey et al., 1998; Barrette et al., 2010). Second, axons do not grow into intact nerves (Langley and Anderson, 1904; Brown et al., 1991a; Bedi et al., 1992; Agius and Cochard, 1998; Luk et al., 2003). Proposed rationales for these effects include physical obstruction of axonal elongation into the nondegenerating nerve segment, lack of clearance of growth inhibitory factors, and decreased secretion of neurotrophic factors by the distal nerve (Bisby and Chen, 1990; Perry and Brown, 1992; Chen and Bisby, 1993), all three of which could result from decreased monocyte influx (Lunn et al., 1989; Brown et al., 1991b; Barrette et al., 2008).

However, these arguments do not take into account the fact that a second site of macrophage accumulation exists after axonal injury. Our laboratory and $\mathrm{Lu}$ and Richardson demonstrated in the 1990s that infiltration also occurs around axotomized neuronal cell bodies (Lu and Richardson, 1993; Schreiber et al., 1995), an effect preceded by expression of the macrophage chemokine CCL2 by these neurons (Schreiber et al., 2001; Tanaka et al., 2004). Therefore, we examined this second site of macrophage 
accumulation in two mutant mouse strains in which accumulation in the distal nerve is inhibited. Finding a clear inhibition also in peripheral ganglia, we tested the hypothesis, which is generally assumed to be true, that neurite outgrowth from sensory and sympathetic neurons from these mutant animals would be normal if they were cultured on a permissive substrate. Our findings contradict this hypothesis and instead strongly support the novel proposal that macrophages act within peripheral ganglia to promote nerve regeneration independent of any effects on Wallerian degeneration.

\section{Materials and Methods}

Animal surgeries. Eight- to 12-week-old male and female wild-type (WT) mice [C57BL/6NHsd (Harlan Laboratories) or C57BL/6J (The Jackson Laboratory)] and mutant mice [C57BL/6OlaHsd-Wld ( $W l d^{s}$; Harlan Laboratories) or C57B6.129S4-Ccr2 ${ }^{\text {tmllff } / J ~(C C R 2 ~}{ }^{-/-}$; The Jackson Laboratory)] were used for this study. The animals were housed under a $12 \mathrm{~h}$ light/dark cycle with ad libitum access to food and water. The superior cervical ganglia (SCGs) and the fifth lumbar dorsal root ganglia (L5 DRGs) were axotomized unilaterally under isoflurane anesthesia by transecting the postganglionic axons of the SCG (the internal and external carotid nerves) near their exits from the ganglion and the sciatic nerve at midthigh level. For the sciatic nerve, a $2 \mathrm{~mm}$ piece of the distal nerve segment was then removed. The contralateral sciatic nerve and ganglia served as internal controls. Six, 24, or $48 \mathrm{~h}$ or $7 \mathrm{~d}$ later, the animals were killed by $\mathrm{CO}_{2}$ inhalation, and the SCG, L5 DRG, sciatic nerves, and submandibular glands were removed for immunohistochemical or molecular biological analysis. All surgical procedures were approved by the Case Western Reserve University Institutional Animal Care and Use Committee.

Immunohistochemistry. Axotomized and contralateral SCG, L5 DRG, and sciatic nerves from $W l d^{s}, C C R 2^{-1-}$, and WT mice were removed $7 \mathrm{~d}$ after unilateral axotomy, and the ganglia were desheathed and fixed by immersion in $4 \%$ paraformaldehyde. The tissues were cryoprotected in $30 \%$ sucrose and embedded in Tissue-Tek O.C.T. compound (Electron Microscopy Sciences). Immunohistochemistry (IHC) was performed on $10 \mu \mathrm{m}$ cryostat sections. For quantification of macrophages, a rat monoclonal antibody to CD11b (also known as Mac1, CR3, and integrin $\alpha_{\mathrm{M}}$; 1:100; Millipore) was incubated with tissue sections overnight at $4^{\circ} \mathrm{C}$. Although CD11b can stain both macrophages and neutrophils, few neutrophils are found in the peripheral nervous system $7 \mathrm{~d}$ after nerve injury (Perry, 1994; Nadeau et al., 2011; J.A.L., A.D.-L., and R.E.Z., unpublished observations). After washing, the sections were incubated in DyLight 549 secondary antibody (1:400; Jackson ImmunoResearch) for $1 \mathrm{~h}$. To assess Wallerian degeneration in the sympathetic system, submandibular glands were dissected $7 \mathrm{~d}$ after SCG axotomy and prepared for IHC as described above. Submandibular gland sections were incubated with a rabbit polyclonal antibody to tyrosine hydroxylase (TH; 1:500; PelFreez) for $2 \mathrm{~h}$ at room temperature. After washing, the sections were incubated with a Cy3 secondary antibody (1:400; Jackson ImmunoResearch) for $45 \mathrm{~min}$. In all experiments, sections not exposed to the primary antiserum were included for each experimental group. Images were captured at $25 \times$ magnification using SimplePCI software (Hamamatsu) and then quantified using MetaMorph software (version 7.6.3.0; Molecular Devices). The area of the section that was stained is expressed as a percentage of the total area examined. The CD11b data were further analyzed by expressing each ipsilateral ganglion as a percentage increase over the contralateral ganglion in the same animal.

Real-time PCR. The expression of CCL 2 mRNA was analyzed by real-time RT-PCR. The procedures followed have been described previously by Habecker et al. (2009). Six, 24, and $48 \mathrm{~h}$ after unilateral axotomy, ipsilateral and contralateral ganglia from $W l d^{s}$ and WT mice were removed and stored in RNAlater (Invitrogen) at $4^{\circ} \mathrm{C}$. RNA was extracted from pairs of ipsilateral and contralateral ganglia using the Ambion RNAqueous micro kit. Three to six samples were included for each time point. Total RNA was quantified, and 400 ng were reverse transcribed using a High Capacity cDNA Reverse Transcription Kit (Applied Biosystems). RT-PCR was performed in an ABI Step-One Plus, using prevalidated TaqMan expression assays [CCL2, Mm00441242_m1; glyceraldehyde-3-phosphate dehydrogenase (GAPDH),
Mm99999915_g1; Applied Biosystems], and samples were assayed in triplicate. CCL2 mRNA values were normalized for each sample to the mRNA for GAPDH, which served as an internal control.

Ganglion explants. To assess the outgrowth of peripheral neurons in response to injury, we evaluated neurite outgrowth in explanted ganglia after a conditioning lesion (Shoemaker et al., 2005). Seven days after unilateral axotomy, the ipsilateral and contralateral SCGs and L5 DRGs from $W l d^{s}, C C R 2^{--1}$, and WT mice were removed, desheathed, placed on coverslips, and overlaid with $7.5 \mu$ l of Matrigel (Becton Dickinson). Culture plates were placed in a $37^{\circ} \mathrm{C}$ incubator for $5 \mathrm{~min}$ to allow gelling of the Matrigel before adding $1 \mathrm{ml}$ of F-12 medium with the additives described previously by Hyatt Sachs et al. (2010). Phase-contrast images of neurite outgrowth from each SCG and each DRG were captured at 24 and $48 \mathrm{~h}$ after explantation using a Zeiss Axiovert $405 \mathrm{M}$ microscope at $10 \times$ magnification. Neurite outgrowth was assessed using MetaMorph software by measuring the distance between the edge of the ganglion and the leading tip of the longest 20 processes in each explant.

Ganglion dissociated cell cultures. To assess neurite outgrowth by isolated sensory neurons, we dissociated and cultured neurons from DRGs (Sachs et al., 2007). Seven days after unilateral transection of the sciatic nerve, ipsilateral and contralateral L5 DRGs from $W l d^{s}, C C R 2^{-/-}$, and WT mice were removed and desheathed. Except when noted, all reagents used in the DRG and SCG dissociations and culture were from SigmaAldrich. Ganglia were incubated in $0.125 \%$ collagenase A at $37^{\circ} \mathrm{C}$ for $1.5 \mathrm{~h}$. The cells were then dissociated by gentle trituration using a P200 pipette in Neurobasal A medium containing 2\% B-27 serum-free supplement, $2 \mathrm{~mm}$ glutamine (both from Invitrogen), $10 \mathrm{U} / \mathrm{ml}$ penicillin, and $10 \mu \mathrm{g} / \mathrm{ml}$ streptomycin. The dissociated cells were purified following the procedure of Gavazzi et al. (1999) by centrifugation through 15\% BSA at $600 \mathrm{rpm}$ for $6 \mathrm{~min}$. Neurons were resuspended in Neurobasal A containing $50 \mu \mathrm{g} / \mathrm{ml}$ DNase (type I) and centrifuged at $1000 \mathrm{rpm}$ for $2 \mathrm{~min}$. Supernatant was removed, and cells were resuspended in Neurobasal A. Cells were gently plated (one DRG per coverslip) onto $22 \mathrm{~mm}$ coverslips coated with $0.01 \%$ poly-L-lysine and $10 \mu \mathrm{g} / \mathrm{ml}$ laminin in a six-well culture plate. Cells were allowed to adhere undisturbed for $20 \mathrm{~min}$. Each coverslip was then overlaid with $2 \mathrm{ml}$ of Neurobasal A and cultured for $24 \mathrm{~h}$ at $37^{\circ} \mathrm{C}$ in $95 \%$ air $/ 5 \% \mathrm{CO}_{2}$.

To assess neurite outgrowth by isolated sympathetic neurons, we cultured dissociated SCGs (Hyatt Sachs et al., 2010). Seven days after unilateral axotomy, ipsilateral and contralateral SCGs were removed, desheathed, cut into six pieces, and incubated in $0.1 \%$ collagenase A at $37^{\circ} \mathrm{C}$ for $40 \mathrm{~min}$. After washing, SCG were incubated in $0.1 \%$ trypsin at $37^{\circ} \mathrm{C}$ for $10 \mathrm{~min}$. Cells were then dissociated in F-12/Coon's medium containing $340 \mathrm{ng} / \mathrm{ml}$ tri-iodo thyronine, $60 \mathrm{ng} / \mathrm{ml}$ progesterone, 400 $\mathrm{ng} / \mathrm{ml}$ L-thyroxine, $38 \mathrm{ng} / \mathrm{ml}$ sodium selenite, $16 \mu \mathrm{g} / \mathrm{ml}$ putrescine, 10 $\mathrm{U} / \mathrm{ml}$ penicillin, $10 \mu \mathrm{g} / \mathrm{ml}$ streptomycin, and 3.5\% Path-4 BSA (MP Biomedicals) by gentle trituration using a P200 pipette. Cells were gently plated (half of a SCG per coverslip) onto $22 \mathrm{~mm}$ coverslips as described above for DRG neurons and allowed to adhere. Each coverslip was then overlaid with $2 \mathrm{ml}$ of F-12/Coon's medium and cultured for $24 \mathrm{~h}$ at $37^{\circ} \mathrm{C}$ in $95 \%$ air $/ 5 \% \mathrm{CO}_{2}$.

Analysis of neurite outgrowth in cultured neurons. Cells were fixed in $4 \%$ paraformaldehyde for $20 \mathrm{~min}$ at room temperature, washed in PBS, and labeled with a mouse monoclonal antibody to $\beta$ III-tubulin (1:900 for DRG and 1:800 for SCG; Promega), followed by a $45 \mathrm{~min}$ incubation in an Alexa Fluor-488-labeled secondary antibody (1:400; Invitrogen). Coverslips were placed onto slides with FluoroGel (Electron Microscopy Sciences). Neurons were visualized with a Leitz epifluorescence microscope (Leica) at $10 \times$ or $25 \times$, and images were captured with a Hamamatsu ORCA 100 cooled CCD camera interfaced with SimplePCI software. MetaMorph was used to measure the longest neurite from each $\beta$ III-tubulin-positive neuron with a process of at least 1.5 times the diameter of the cell body.

Myelin visualization. To assess Wallerian degeneration in the sciatic nerve, myelin was visualized $7 \mathrm{~d}$ after unilateral axotomy. Cryostat sections were rehydrated in distilled water for $5 \mathrm{~min}$ and dehydrated in 35\% and $70 \%$ ethanol for $5 \mathrm{~min}$ each. They were then incubated in $0.1 \%$ Luxol fast blue (LFB) overnight at $60^{\circ} \mathrm{C}$, followed by washes in $95 \%$ ethanol and distilled water. The sections were then destained in $0.05 \%$ lithium car- 
a

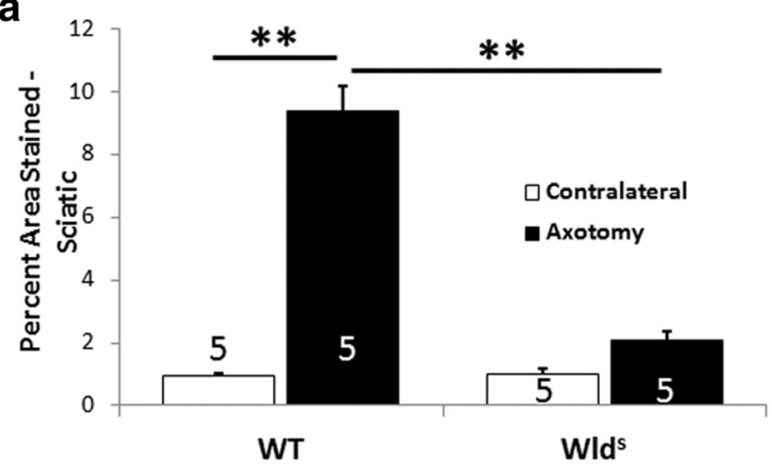

b

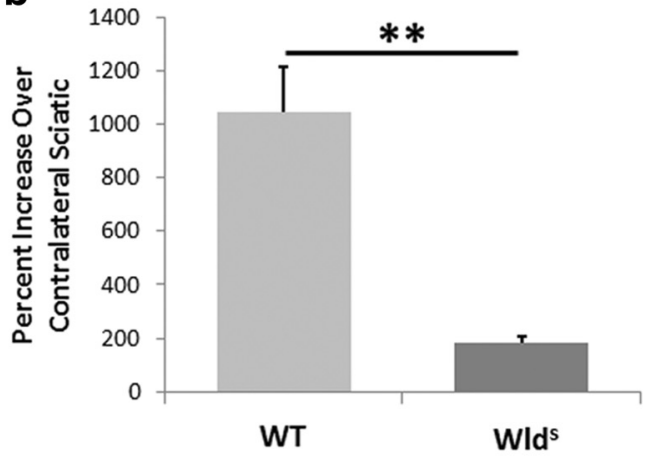

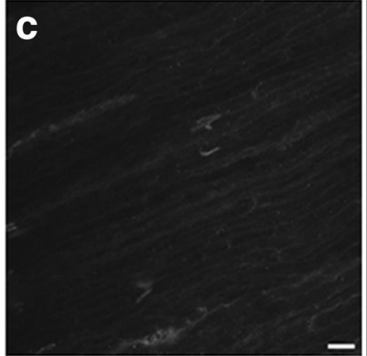
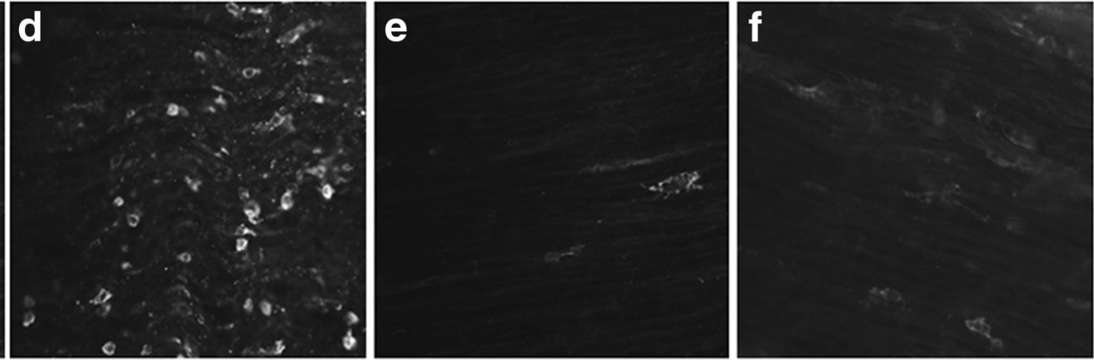

Figure 1. Macrophage accumulation is significantly increased in the distal segment of the transected sciatic nerve in WT mice but not in WId ${ }^{5}$ mice. The sciatic nerve in WT and WId ${ }^{s}$ mice was transected unilaterally (Axotomy), and, $7 \mathrm{~d}$ later, the nerve segment distal to the site of transection was immunostained with a CD11b antibody to visualize macrophages. A comparable segment of the contralateral nerve was also examined. The extent of staining was quantitated as a percentage of the section area that was stained ( $\boldsymbol{a}$ ). The number of nerves examined in each group is given within each bar of the histogram. The staining in the axotomized nerve is also expressed as a mean ratio of staining in the ipsilateral and contralateral nerves for each animal $\times 100(\boldsymbol{b})$. Micrographs are shown for contralateral $(\boldsymbol{c}, \boldsymbol{e})$ and axotomized $(\boldsymbol{d}, \boldsymbol{f})$ nerves from WT $(\boldsymbol{c}, \boldsymbol{d})$ and WId $\boldsymbol{d}^{5}(\boldsymbol{e}, \boldsymbol{f})$ animals. The data presented here and in all subsequent figures are means \pm SEM. ${ }^{* *} p<0.001$. Scale bar, $20 \mu \mathrm{m}$

bonate for $30 \mathrm{~s}$, rinsed in 70\% ethanol, and incubated in 70, 95, and 100\% ethanol for $5 \mathrm{~min}$ each. Finally, the sections were transferred to xylene for 5 min and examined under a light microscope. The extent of staining was quantified as described above for TH.

Statistics. Data are expressed as the means \pm SEM and were analyzed by one-way ANOVA (PCR data and comparisons of the ratio of CD11b staining between axotomized and contralateral tissues) or two-way ANOVA, followed by Tukey's post hoc test. $p$ values $<0.05$ were considered statistically significant.

\section{Results}

Decreased axotomy-induced macrophage influx into sensory and sympathetic ganglia in the $W l d^{s}$ mouse

As indicated previously, the $W l d^{s}$ mouse exhibits little macrophage accumulation in the distal sciatic nerve segment 1 week after nerve transection (Lunn et al., 1989; Brown et al., 1991b). Later, it was shown that this effect represented a delay, rather than a block, in macrophage accumulation (Sommer and Schäfers, 1998). As a positive control for our immunohistochemical experiments in peripheral ganglia, we also examined the accumulation of macrophages in the distal segment of the sciatic nerve $7 \mathrm{~d}$ after nerve transection in WT and $W l d^{s}$ mice. Whereas a large increase in macrophages was found in the nerves of WT animals, no significant increase was found in the $W l d^{s}$ mouse, confirming these earlier studies (Fig. 1a-f).

If the phenotype of the $W l d^{s}$ mouse after axotomy was entirely restricted to the distal nerve segment, as has generally been assumed, there would be no reason to expect a change in monocyte entry into the L5 DRG, which is $\sim 2 \mathrm{~cm}$ away from the injury site. Nevertheless, whereas a fourfold increase in macrophage accumulation was seen in the DRGs of WT mice $7 \mathrm{~d}$ after axotomy (Fig. 2a-d), no significant increase was seen in $W l d^{s}$ mice (Fig. 2a,b,e,f).
We next explored this phenomenon in a sympathetic ganglion, the SCG. Here, as in the DRGs, the increase in macrophage influx into the ganglia in WT mice was substantial (3.6-fold; Fig. $2 g$ ). There was also a significant increase in SCGs from $W l d^{s}$ mice (Fig. $2 g$ ), but the density of macrophages was significantly less than in WT ganglia (Fig. $2 g, i-l$ ). Thus, similar to the reduced accumulation of macrophages in the distal nerve stump after axonal transection, there is a reduced accumulation in regions of axotomized neuronal cell bodies in Wld mice. The difference between the results in DRGs and SCGs can be seen most dramatically by considering the percentage increases in macrophage staining between the WT and Wlds mice (Fig. $2 b, h$ ).

\section{Regulation of CCL2 mRNA in peripheral ganglia after axotomy}

What might account for the decreased macrophage accumulation in these ganglia? As already noted, CCL2 mRNA is increased in neurons in both sensory and sympathetic ganglia within hours after axotomy, and therefore can be considered a regenerationassociated gene (RAG; Schreiber et al., 2001; Costigan et al., 2002; Boeshore et al., 2004; Tanaka et al., 2004). We sought to determine whether expression of this gene differed in WT and Wld mice. L5 DRGs were examined 6, 24, and $48 \mathrm{~h}$ after the sciatic nerve was transected unilaterally. CCL2 mRNA was not detected in contralateral ganglia from either genotype at any of the three time points examined. In the axotomized DRGs, CCL2 mRNA was detected in both genotypes at all time points; however, the levels in the ganglia from WT mice were significantly higher than in $W l d^{s}$ mice at 24 and $48 \mathrm{~h}$, and the difference was very close to significance at $6 \mathrm{~h}$ (Fig. $3 a$ ). 


\section{a}

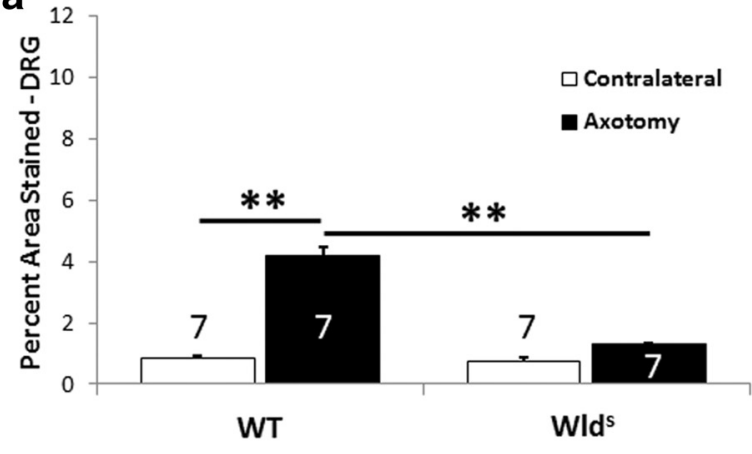

b

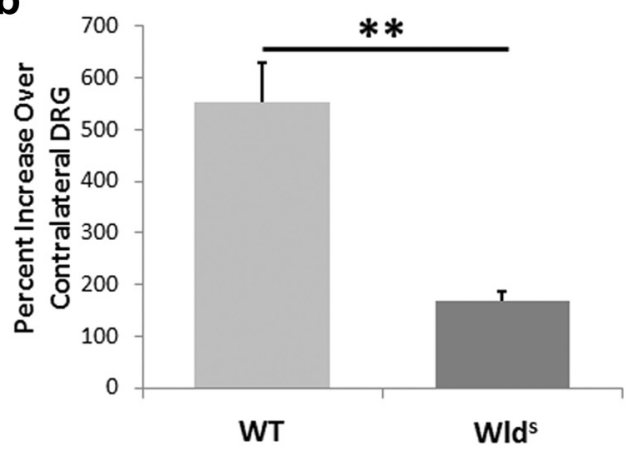

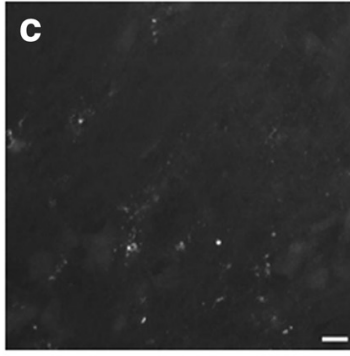

g

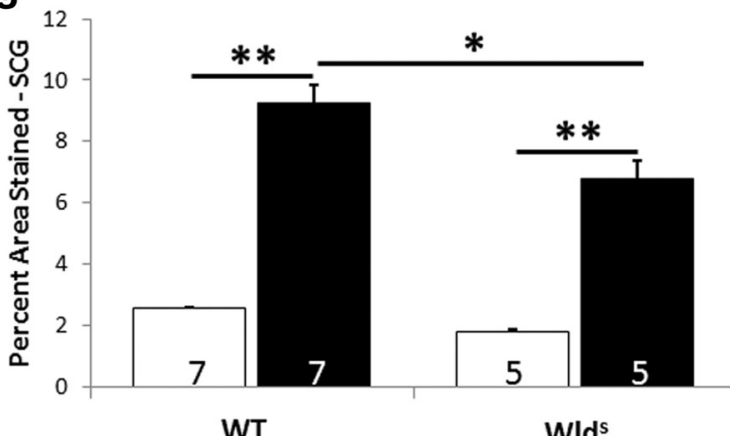

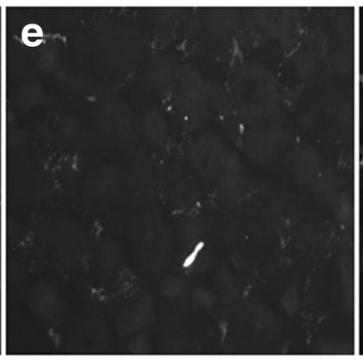

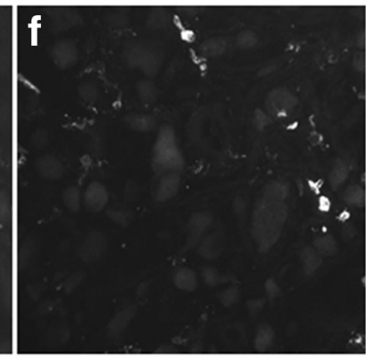

h

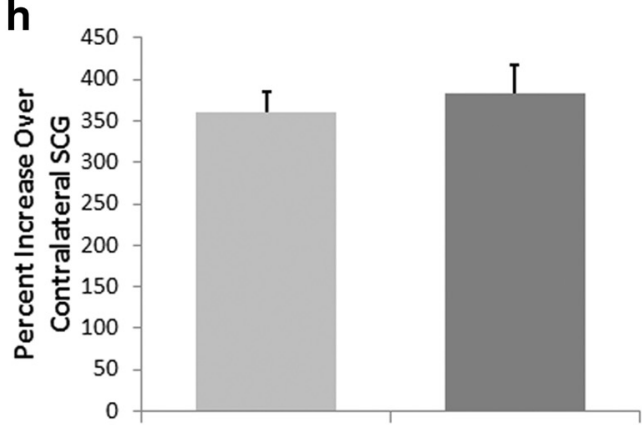

WT

WIds
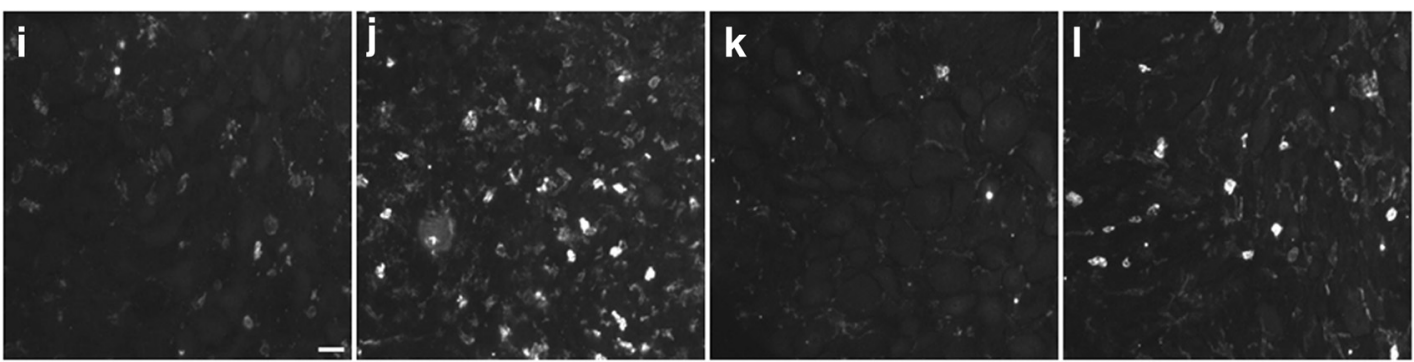

Figure 2. The macrophage accumulation in L5 DRGs and SCGs after unilateral axotomy is significantly diminished in WId ${ }^{5}$ mice compared with WT mice. The tissues examined were from the same groups of animals. Seven days after unilateral transection of the relevant nerves, the ipsilateral and contralateral ganglia were removed and immunostained for CD11b-positive cells. The data are presented as both the percentage of the section area that was stained $(\boldsymbol{a}, \boldsymbol{g})$ and the mean ratio of staining in the ipsilateral and contralateral ganglia for each animal $\times 100(\boldsymbol{b}, \boldsymbol{h})$. Micrographs are shown for contralateral DRGs $(\boldsymbol{c}, \boldsymbol{e})$ and SCGs $(\boldsymbol{i}, \boldsymbol{k})$ and axotomized DRGs $(\boldsymbol{d}, \boldsymbol{f})$ and SCGs $(\boldsymbol{j}, \boldsymbol{I})$ from WT $(\boldsymbol{c}, \boldsymbol{d}, \boldsymbol{i}, \boldsymbol{j})$ and $W I d^{5}(\boldsymbol{e}, \boldsymbol{f}, \boldsymbol{k}, \boldsymbol{I})$ mice. ${ }^{*} p<0.05,{ }^{* *} p<0.001$. Scale bars, $20 \mu \mathrm{m}$.

CCL2 mRNA was also undetected in contralateral SCGs of both genotypes. The elevation of this chemokine after axotomy was significantly greater in SCGs from WT animals compared with those from $W l d^{s}$ animals at all time points examined (Fig. $3 b$ ). These data indicate that the difference in CCL2 expression is likely to be the cause of the reduced accumulation of macrophages in axotomized ganglia in the $W l d^{s}$ mouse.

\section{Macrophage accumulation in sensory and sympathetic} ganglia in the $C C R 2^{-/-}$mouse

CCL2 produces its chemotactic effect on circulating monocytes via the CCR2 receptor (Deshmane et al., 2009). For example, this receptor has been shown to be important for monocyte infiltration into the lesioned sciatic nerve (Siebert et al., 2000). Nevertheless, there are no data available on whether monocyte entry into peripheral ganglia after axotomy is dependent on CCL2, CCR2, or both of them. We examined this question in WT mice and in mice in which CCR2 had been knocked out.

As a starting point, we examined macrophage accumulation in the distal segment of the sciatic nerve $7 \mathrm{~d}$ after nerve transection in WT and CCR2 $2^{-/-}$mice. In our hands, the increase in macrophage accumulation after axotomy was totally abolished in the knock-out animals (Fig. $4 a-e$ ). Furthermore, as shown previously, in WT animals $7 \mathrm{~d}$ after unilateral nerve transection, 

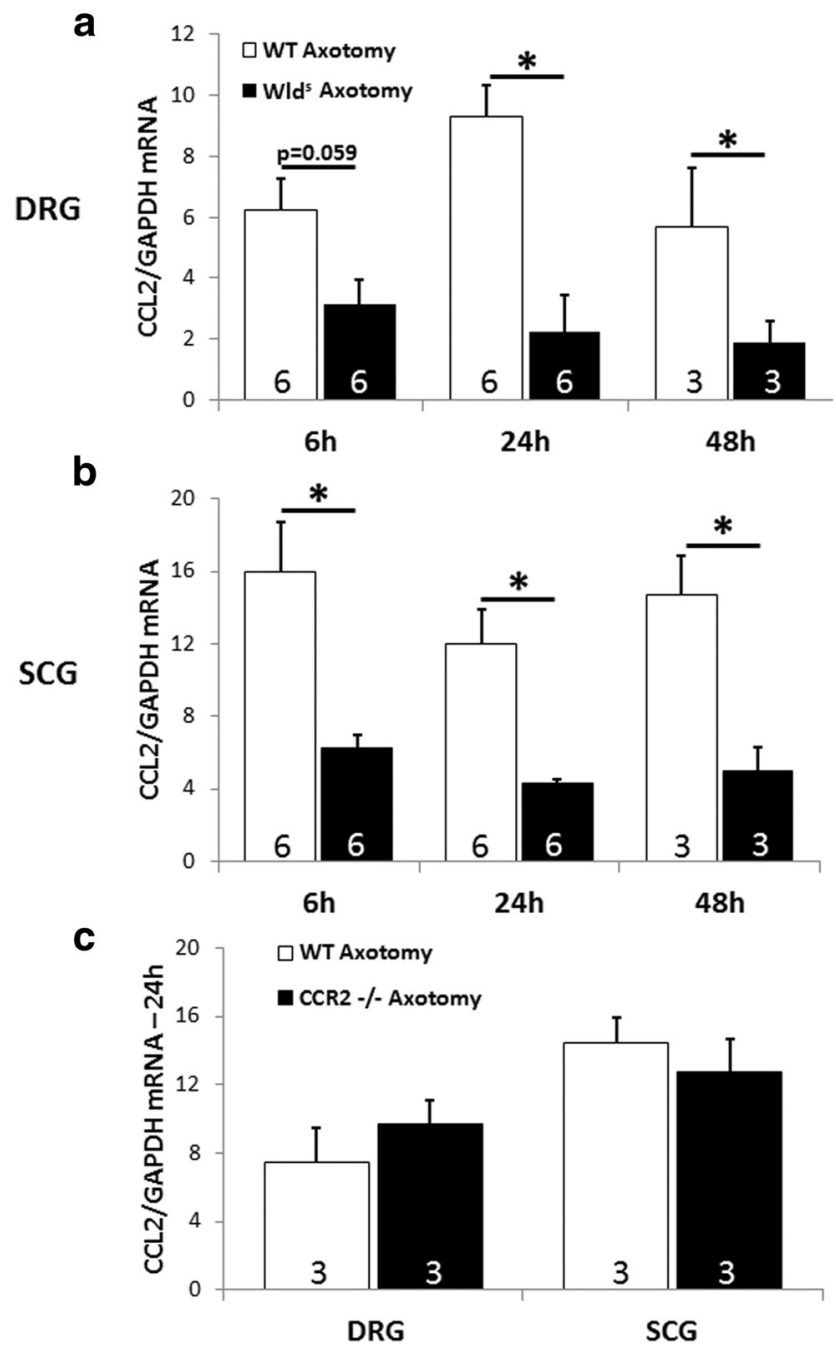

Figure 3. The axotomy-induced induction of CCL2 is diminished in DRGs (a) and SCGs (b) in WId mice compared with WT mice. Six, 24 , and $48 \mathrm{~h}$ after transection of the relevant nerves, axotomized and contralateral L5 DRGs and SCGs were extracted, and CCL2 mRNA was measured by RT-PCR. № detectable CCL2 mRNA was found in the contralateral ganglia. CCL2 mRNA was also measured in axotomized DRGs and SCGs from WT and CCR2 ${ }^{-1}$ mice 24 hafter axotomy. No differences were seen (c). The data are normalized to GAPDH mRNA for each sample. ${ }^{*} p<0.05$.

macrophage accumulation in the ipsilateral L5 DRG is dramatically increased (Fig. $4 f-h$ ); however, no significant increase was seen under the same conditions in the $C C R 2^{-1-}$ mouse (Fig. $4 f, i, j)$. In the SCG, although there was an increase in macrophage accumulation in ganglia from $C C R 2^{-/-}$mice (Fig. $4 k, n, o$ ), the density of macrophages was significantly smaller than that seen in ganglia from WT animals (Fig. $4 k-m$ ). These data raise the possibility that, in the SCG, a second chemokine in addition to CCL2 might be involved in bringing monocytes into the ganglion after axotomy.

The level of CCL2 mRNA was also determined in DRGs and SCGs in CCR2 $2^{-/-}$mice $24 \mathrm{~h}$ after axotomy. No differences were found between WT and CCR2 $2^{-1-}$ mice (Fig. $3 c$ ).

\section{Wallerian degeneration in $W l d^{s}$ and $C C R 2^{-/-}$mice}

Wallerian degeneration in the mutant mice was compared with that in WT mice. As originally shown by Lunn et al. (1989) and replicated by others, little Wallerian degeneration was seen in $W l d^{s}$ mice 1 week after transection of the sciatic nerve (Fig. $5 a, c, f)$, measured in our experiments by the disappearance of staining for myelin proteins. Because it is widely believed that normal Wallerian degeneration is dependent on infiltrating monocytes into the distal nerve (Brück, 1997; Dailey et al., 1998; Luk et al., 2003; Barrette et al., 2008; Vargas et al., 2010; Gaudet et al., 2011; Rotshenker, 2011) and because there was no significant influx of macrophages in the sciatic nerves of the $C C R 2^{-/-}$mice $7 \mathrm{~d}$ after transection (Fig. $4 a$ ), we assumed that Wallerian degeneration would be slow in these animals. However, the clearance of myelin proteins in CCR2 $2^{-/-}$mice at $7 \mathrm{~d}$ was similar to that in WT mice and dramatically different from that in the $W l d^{s}$ mice (Fig. $5 a, d, g)$.

As of yet, there have been no reports of the relative speed of Wallerian degeneration in the sympathetic nervous system among $\mathrm{WT}, W l d^{s}$, and CCR2 $2^{-1-}$ mice. Therefore, we determined whether sympathetic axons from $W l d^{s}$ and $C C R 2^{-1-}$ mice in fact exhibit slow Wallerian degeneration. For this purpose, we examined the sympathetic innervation of one of the main targets of the SCG, the submandibular gland (Flett and Bell, 1991), using IHC for TH, the cytoplasmic enzyme that catalyzes the rate-limiting step in catecholamine biosynthesis. This approach was chosen because TH is localized specifically in sympathetic neurons. Seven days after the internal and external carotid nerves were severed, TH immunoreactivity was no longer detectable in the submandibular glands of WT mice (Fig. $6 a, b, e)$; however, considerable staining persisted in the glands from $W l d^{s}$ mice (Fig. $\left.6 a, c, f\right)$. In contrast, the disappearance of TH immunoreactivity in $C C R 2^{-1-}$ mice was similar to that seen in WT mice (Fig. $6 a, d, g$ ).

These data on Wallerian degeneration in the sciatic nerve and submandibular gland are of considerable interest in the interpretation of the results on neurite outgrowth presented in the following sections because although both $W l d^{s}$ and $C C R 2^{-1-}$ mice have no significant increase in macrophage accumulation in the distal nerve segment; only the $W l d^{s}$ mice have slow Wallerian degeneration.

\section{The conditioning lesion effect in DRG and SCG explants from Wld $d^{s}$ mice}

It has been established that regeneration of the sciatic nerve after nerve crush is decreased, or perhaps delayed, in Wld ${ }^{s}$ mice. As noted previously, this decrease has been attributed to the slow Wallerian degeneration that occurs in these animals. Based on this universally accepted view, neurite outgrowth from peripheral ganglia placed in a permissive growth environment would be expected to be normal. Nevertheless, given our finding of a decreased expression of an RAG in $W l d^{5}$ neurons in sensory and sympathetic ganglia and a change in the non-neuronal cellular environment of the axotomized neurons, we wondered whether these neurons might also exhibit a smaller increase in outgrowth in vitro in response to axotomy. To examine this possibility, we first looked at neurite outgrowth in explant cultures (i.e., in the absence of the distal nerve stump) $7 \mathrm{~d}$ after a conditioning lesion. Both DRGs and SCGs from WT animals have been shown to have increased outgrowth under these conditions (Ekström et al., 2003; Shoemaker et al., 2005; Hyatt Sachs et al., 2010).

As expected, DRG neurons from WT animals $7 \mathrm{~d}$ after a conditioning lesion exhibited an increase in neurite outgrowth both 24 and $48 \mathrm{~h}$ after explantation (Fig. $7 a-c$ ); however, in ganglia from $W l d^{s}$ mice, there was no significant effect of the conditioning lesion at either time (Fig. $7 a, b, d$ ). In striking contrast, in the SCG, comparable conditioning lesion responses were observed in ganglia from both WT (2.3-fold increase) and Wld ${ }^{\text {s }}$ (2.3-fold increase) mice at $48 \mathrm{~h}$, and the magnitudes of these responses were not significantly different (Fig. $7 e-h$ ). 

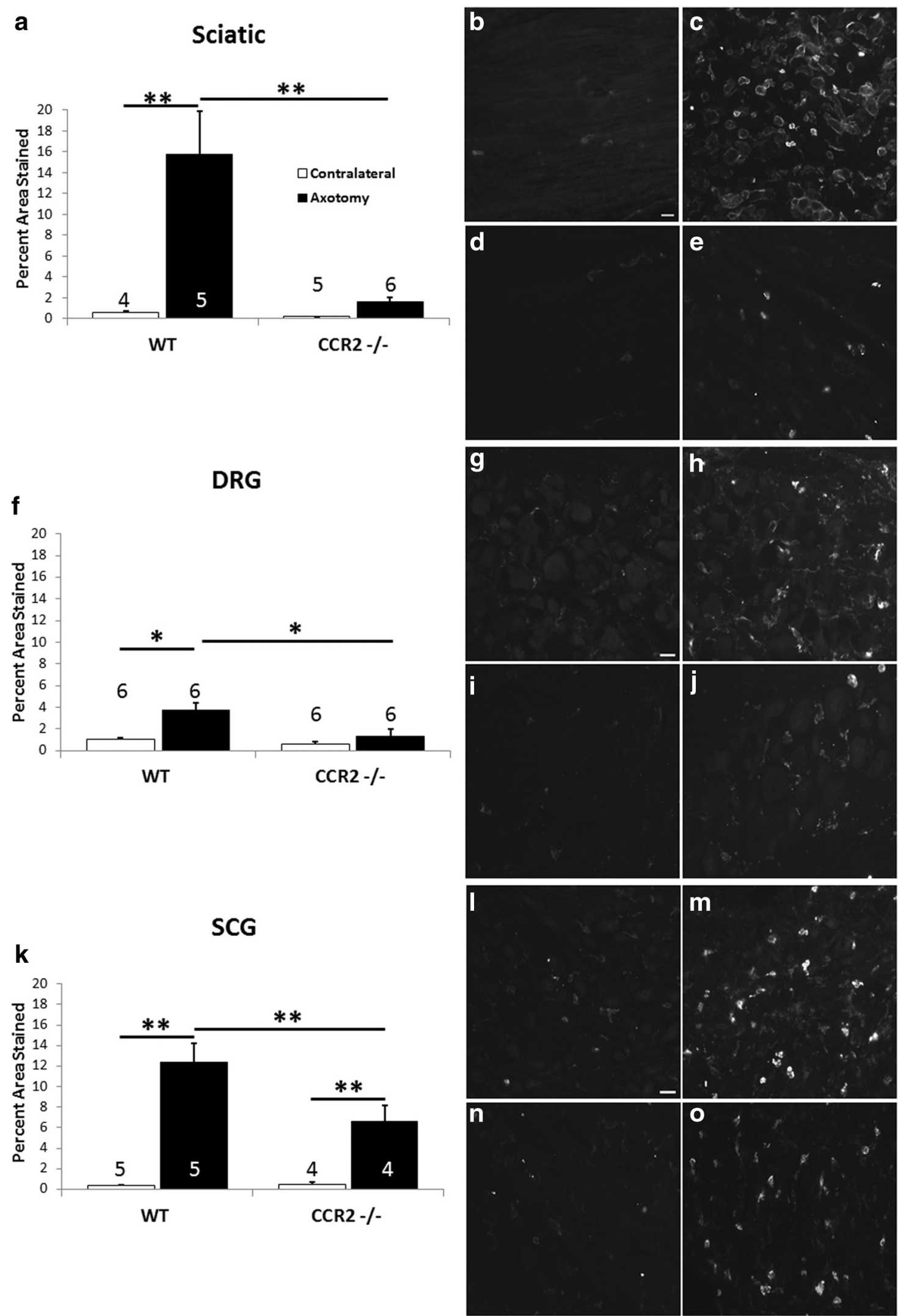

Figure 4. The axotomy-induced accumulation of macrophages in the sciatic nerve, DRG, and SCG is diminished in $C C R 2^{-1-}$ mice compared with WT mice. The data show the extent of CD11b staining in sciatic nerves from WT and $C C R 2^{-/-}$mice $7 \mathrm{~d}$ after unilateral axotomy $(\boldsymbol{a})$. No effect of axotomy was seen in the $C_{C R 2^{-/-}}$animals. Representative micrographs are shown from contralateral $(\boldsymbol{b}, \boldsymbol{d})$ and axotomized $(\boldsymbol{c}, \boldsymbol{e})$ sciatic nerves from WT $(\boldsymbol{b}, \boldsymbol{c})$ and $C\left(R 2^{-\prime-}(\boldsymbol{d}, \boldsymbol{e})\right.$ animals. Axotomy-induced macrophage accumulation was abolished also in $\mathrm{L} 5 \mathrm{DRGs}$ from the same animals $(\boldsymbol{f})$. Micrographs are shown from contralateral $(\boldsymbol{g}, \boldsymbol{i})$ and axotomized $(\boldsymbol{h}, \boldsymbol{j})$ DRGs from WT $(\boldsymbol{g}, \boldsymbol{h})$ and $C\left(R 2^{-/-}(\boldsymbol{i}, \boldsymbol{j})\right.$ animals. Axotomy-induced macrophage accumulation is lessened, but not abolished, in the SCGs from CCR2 ${ }^{-/-}$mice $(\boldsymbol{k})$. Micrographs are shown from contralateral $(\boldsymbol{I}, \boldsymbol{n})$ and axotomized $(\boldsymbol{m}, \boldsymbol{o})$ SCGs from WT $(\boldsymbol{I}, \boldsymbol{m})$ and $C\left(R 2^{-/-}(\boldsymbol{n}, \boldsymbol{0})\right.$ animals. ${ }^{*} p<0.05,{ }^{* *} p<0.001$. Scale bars, $20 \mu \mathrm{m}$. 
The conditioning lesion effect in the DRG and SCG from $C C R 2^{-/-}$mice Our data establish that macrophage accumulation in peripheral ganglia after axotomy is abolished or significantly reduced in both $W l d^{s}$ and $C C R 2^{-/-}$mice and that the conditioning lesion response is abolished in explants of the DRGs from Wld mice. Therefore, we examined the growth response to a conditioning lesion in the $C C R 2^{-1-}$ mice. As expected, there was an increase in outgrowth in response to a conditioning lesion in both the DRG (Fig. $8 a-c$ ) and the SCG (Fig. $8 e-g$ ) explants in ganglia taken from WT animals. Strikingly, however, this conditioning lesion effect was abolished in both types of ganglia taken from CCR $2^{-/-}$mice (Fig. $8 a, b, d$ and $e, f, h)$. These results indicate a strong relationship between macrophage accumulation in ganglia and the conditioning lesion response, and they provide a case in which inhibition of the response can be completely dissociated from changes in the rate of Wallerian degeneration.

\section{Examination of the conditioning lesion effect in dissociated neurons from both $W l d^{s}$ and $C C R 2^{-/-}$mice}

To determine whether the decreased neurite outgrowth seen in explants represented, at least in part, a neuron-autonomous effect, we examined the conditioning lesion response in dissociated neuronal cultures. Demonstration that a conditioning lesion response in WT neurons can be seen in dissociated DRG and SCG cultures was first observed by Hu-Tsai et al. (1994) and Shoemaker et al. (2005), respectively.

The longest neurite was measured from every $\beta$ III-tubulin immunostained neuron that had a neurite at least 1.5 times the diameter of the cell body. As we reported previously (Shoemaker et al., 2005; Sachs et al., 2007), $7 \mathrm{~d}$ after a conditioning lesion, there was a substantial increase in neurite outgrowth from both sensory and sympathetic neurons from WT animals (Fig. $9 a, b, e$ and $h, i, l$, respectively). In dissociated neurons from DRGs of both $W l d^{s}$ and CCR2 $2^{-/-}$mice, this conditioning lesion effect was significantly reduced; nevertheless, the effect was not abolished (Fig. 9a). In neurons from SCGs of $W l d^{s}$ mice, no change in the conditioning lesion effect was seen compared with that in WT mice (Fig. 9h,j,m). In sympathetic neurons from $C C R 2^{-1-}$ mice, the conditioning lesion effect was significantly reduced but again not abolished (Fig. $9 h, k, n$ ). Thus, under conditions in which macrophage accumulation in peripheral ganglia is substantially reduced, the conditioning lesion response in neurons dissociated from those ganglia is reduced.

\section{Discussion}

Macrophages are known to foster nerve regeneration; however, virtually all previous studies have assumed that they do so by accumulating in the distal nerve segment, promoting Wallerian degeneration, and perhaps triggering growth factor expression. Such studies include investigations of the $W l d^{s}$ mouse (Brown et al., 1991b) and of blockade of monocyte infiltration into the distal nerve, for example, by means of complement depletion (Dailey et al., 1998) or insertion of a thymidine kinase transgene on the CD11b promoter (Barrette et al., 2008). Under these conditions, both Wallerian degeneration and nerve regeneration are inhibited. Although it has been known for $\sim 20$ years that macrophages also accumulate in axotomized sympathetic and sensory ganglia after axotomy (Lu and Richardson, 1993; Schreiber et al., 1995), no consideration has been given to the possibility that such accumulation was also blocked in these studies.

Macrophage accumulation in the lesioned sciatic nerve depends on CCL2 expression by Schwann cells (Perrin et al., 2005) and by the expression of its receptor CCR 2 on monocytes (Siebert et al., 2000; Abbadie et al., 2003). In addition, in peripheral ganglia, macrophage accumulation is preceded by CCL2 expression by the axotomized neurons (Schreiber et al., 2001; Tanaka et al., 2004). We report here that axotomy-induced macrophage accumulation is totally absent in the L5 DRG in the Wld mouse and that this is accompanied by a substantially smaller increase in CCL2 mRNA compared with that seen in WT ganglia. In the Wld SCG, macrophage accumulation is also reduced, but it is not abolished despite a reduced upregulation of CCL 2 mRNA similar to that in the DRG. These results suggest that a second chemo- 

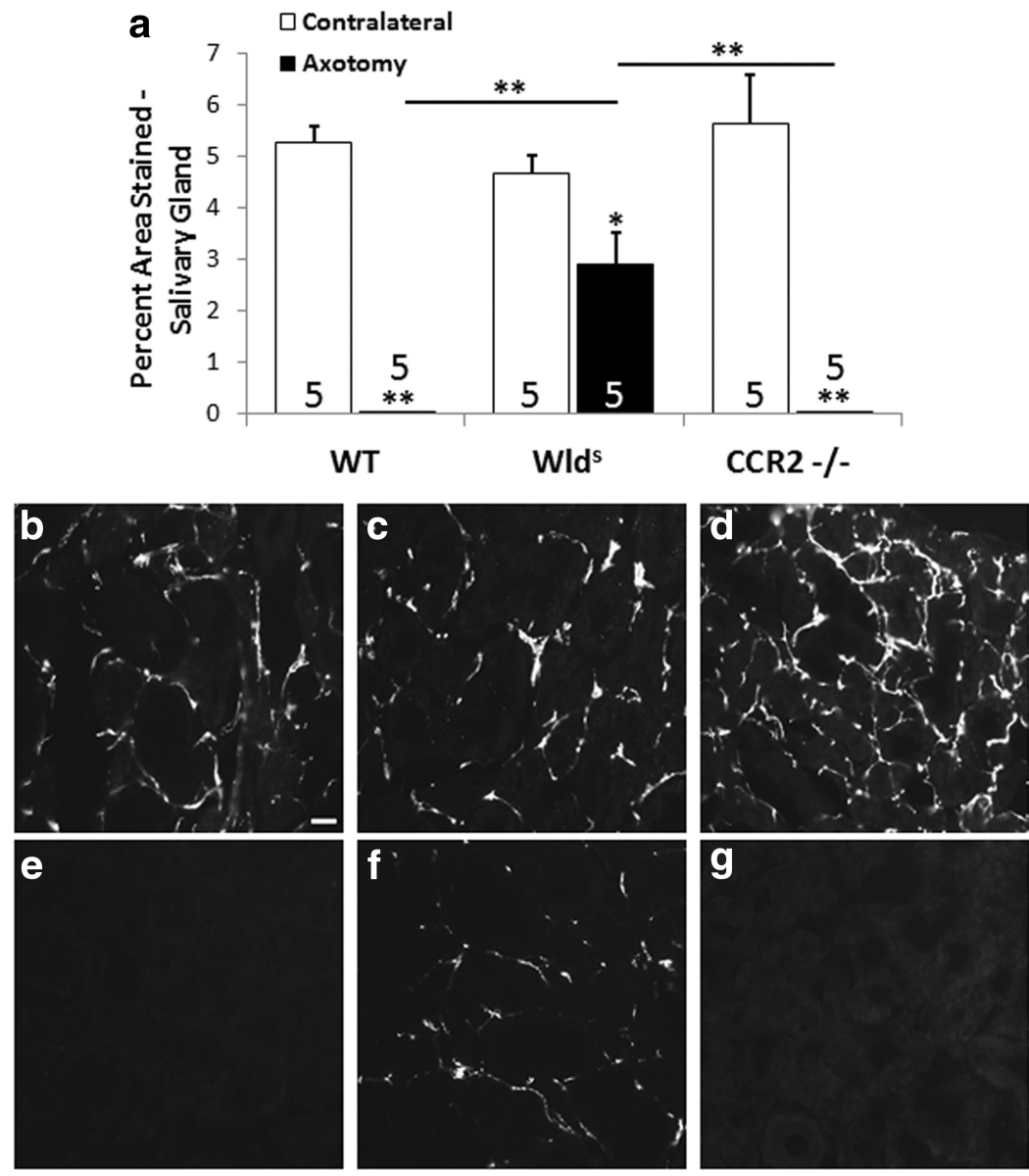

Figure 6. Sympathetic nerve fibers in an autonomic target in the WId mouse, but not the $C^{5}\left(R 2^{-1-}\right.$ mouse, exhibit slow Wallerian degeneration (a). To determine whether sympathetic neurons in vivo in the WId and $\mathrm{CCR}^{-/-}$mouse exhibit slow Wallerian degeneration, the internal and external carotid nerves were transected, and, $7 \mathrm{~d}$ later, the ipsilateral and contralateral submandibular glands were stained for TH in WT, WId , and $C\left(R 2^{-/-}\right.$mice. The micrographs represent sections from the ipsilateral $(\boldsymbol{e}-\boldsymbol{g})$ and contralateral $(\boldsymbol{b}-\boldsymbol{d})$ nerves from WT, WId ${ }^{5}$, and $C C R 2^{-/-}$mice, respectively. ${ }^{*} p<0.05,{ }^{* *} p<0.001$. Scale bar, $20 \mu \mathrm{m}$.

kine, in addition to CCL2, operates in the SCG and a number of candidates exist for this molecule (Surmi and Hasty, 2010; Ingersoll et al., 2011). When we tested the importance of CCL2/CCR2 signaling further by looking at $C C R 2^{-/-}$mice, we again found a total blockade of macrophage accumulation in the DRG and a less robust but significant increase in the SCG.

To test whether these changes in macrophage accumulation in ganglia affect neurite outgrowth, we used the conditioning lesion response. In this response, a previous lesion to a nerve stimulates the regenerative response to a subsequent lesion in vivo (McQuarrie and Grafstein, 1973). The conditioning lesion also increases neurite outgrowth in sensory and sympathetic neurons in explant or dissociated cultures (Hu-Tsai et al., 1994; Edström et al., 1996; White et al., 1996; Shoemaker et al., 2005). We used these in vitro approaches with the $W l d^{s}$ mice because interpretation of in vivo experiments would be complicated by the influence of the nondegenerating distal nerve segment, which as noted is assumed to inhibit regeneration.

In the $W l d^{s}$ DRG explants, neurite outgrowth does not increase after a conditioning lesion. Conversely, in the SCG, no difference was seen in the conditioning lesion response between WT and $W l d^{s}$ mice. A likely explanation is that, whereas macrophage accumulation in the DRG after axotomy was completely abolished in the $W l d^{s}$ mouse, it was only somewhat diminished in the SCG. This relationship between the extent of macrophage accumulation in these two peripheral ganglia and subsequent neurite outgrowth supports our hypothesis that monocyte infiltration into peripheral ganglia plays a crucial role in triggering the conditioning lesion response.

The results of neurite outgrowth obtained in dissociated cell cultures bear both similarities to and differences from those from explants. For example, in both explants and cell cultures, $W l d^{s}$ DRG neurons, but not SCG neurons, exhibited less neurite outgrowth after a conditioning lesion compared with WT animals. Nevertheless, the conditioning lesion effect was not abolished in cell cultures from DRGs as it was in explants.

In both DRG and SCG explant cultures from $C C R 2^{-/-}$mice, no conditioning lesion effect was seen. In dissociated sensory and sympathetic CCR2 $2^{-/-}$neurons, the conditioning lesion effect was significantly reduced, but it was not abolished. Presumably, the differences between explant and cell cultures reflect the disruption of the cellular relationships between neurons and non-neuronal cells and a reduction in the presence of non-neuronal cells (e.g., satellite/Schwann cells, macrophages and other leukocytes, endothelial cells, and fibroblasts). Based on these results, we hypothesize that the effect of macrophages on the conditioning lesion response results in part from a stimulatory neuron-autonomous event and in part from an effect on a non-neuronal cell type, perhaps inhibitory in nature.

A peripheral conditioning lesion also promotes regeneration of the lesioned central processes of DRG neurons (Richardson and Verge, 1987; Chong et al., 1999; Neumann and Woolf, 1999). In a recent article, Salegio et al. (2011) showed that this effect is blocked after intravenous injections of clodronate liposomes, a treatment that decreases the number of circulating monocytes. However, given the systemic effect of these liposomes, macrophages would be decreased at both the CNS and PNS injury sites along with a decrease in the DRGs. Thus, no conclusion can be drawn from the study as to the importance of monocyte entry specifically into the DRG. Lu and Richardson (1991) did report that producing inflammation within the DRG or injecting peritoneal macrophages directly into these ganglia stimulated regeneration of the central, although not the peripheral, process of DRG neurons.

With few exceptions, studies on the $W l d^{s}$ mouse have focused on understanding the mechanism of the $\sim 10$-fold slower degeneration of the distal axonal segment that occurs after axotomy compared with that in WT axons. The expectation from early studies on regeneration in the $W l d^{s}$ mouse has been that delayed regeneration is the direct result of delayed degeneration and that no effects should be seen on neurite outgrowth of $W l d^{s}$ neurons in culture. Another argument against the idea that the delayed regeneration represents a change in the growth response of Wld 


\section{DRG}
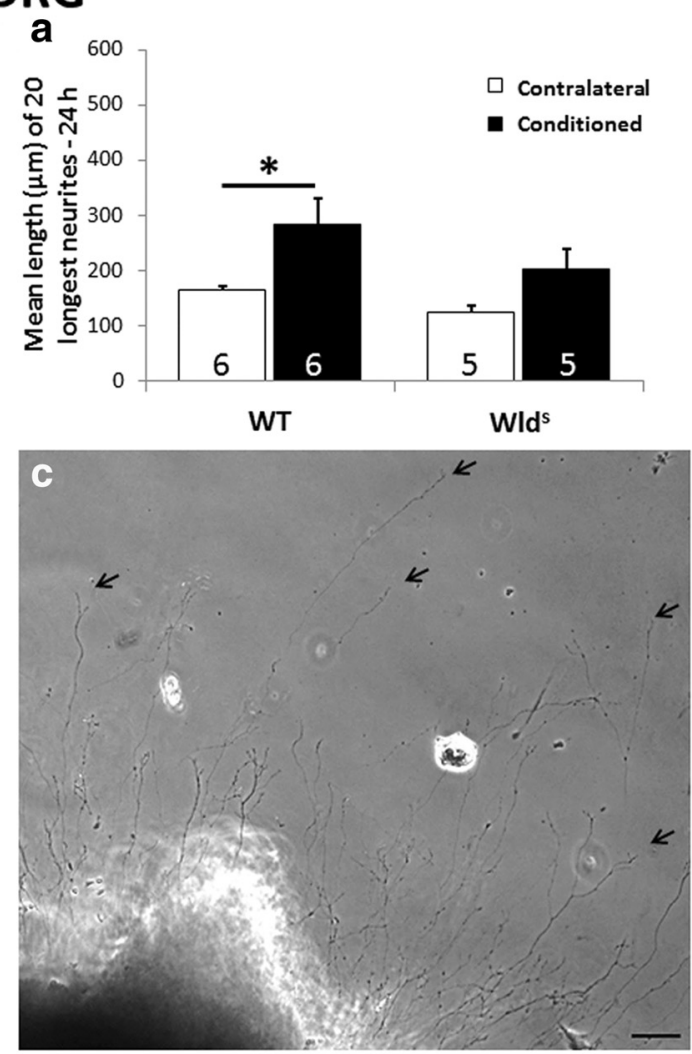

\section{SCG}
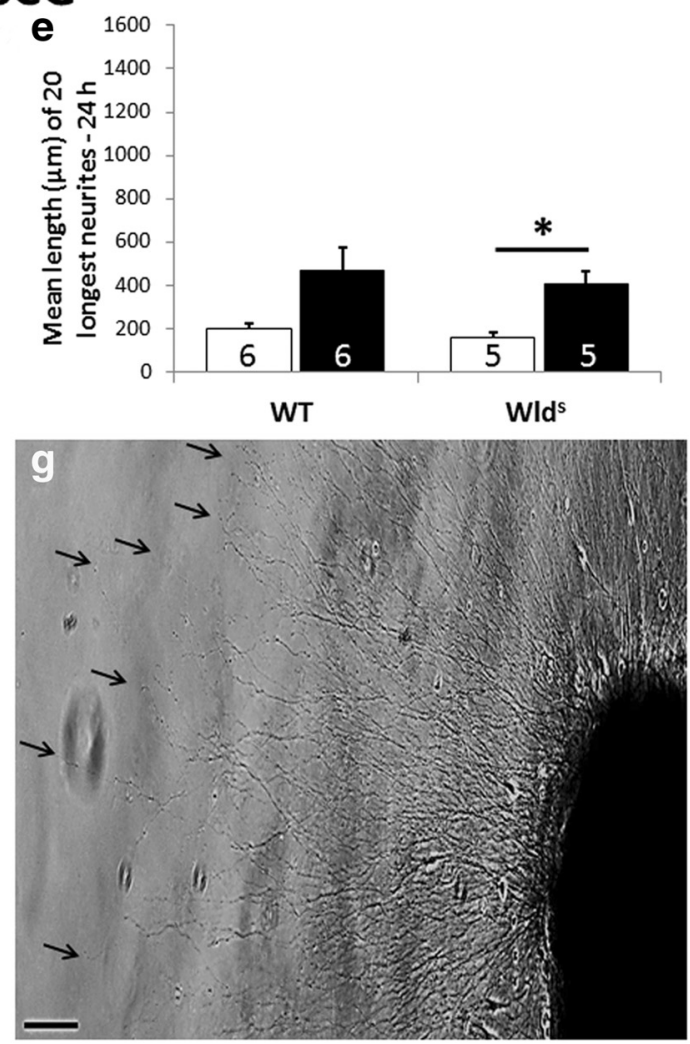
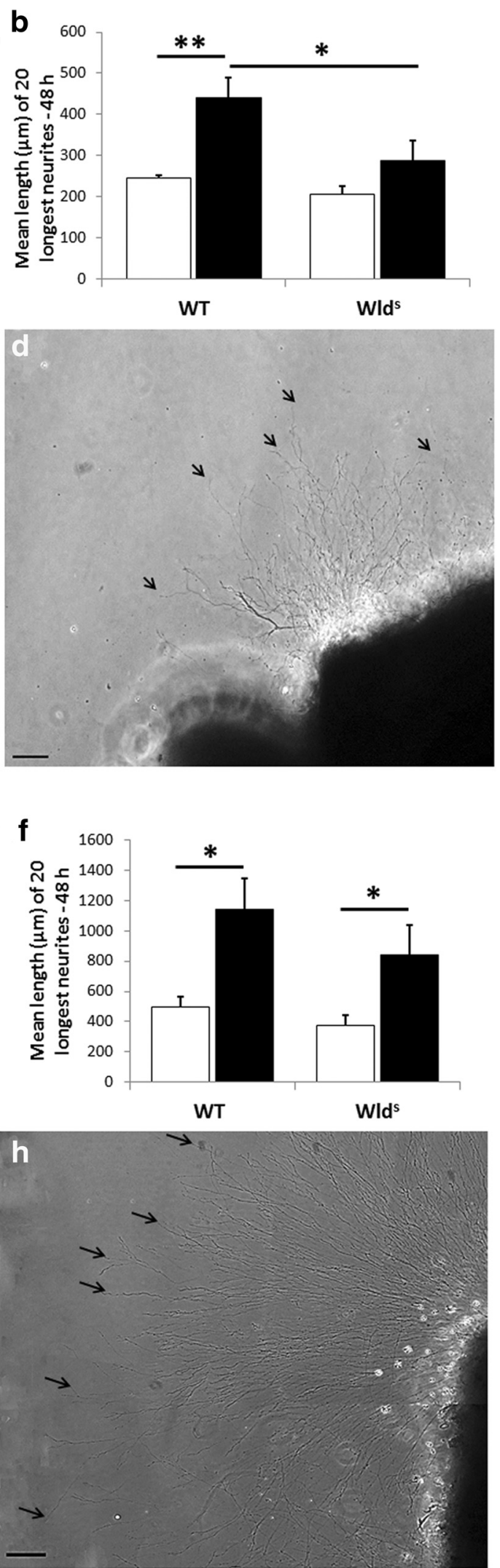

Figure 7. The conditioning lesion effect is abolished in DRG, but not SCG, explants from WId mice. Seven days after unilateral sciatic nerve transection, DRGs were placed in explant culture, and neurite outgrowth was measured after $24 \mathrm{~h}(\boldsymbol{a})$ and $48 \mathrm{~h}(\boldsymbol{b})$. The phase micrographs are of individual conditioned DRG explants from WT $(\boldsymbol{c})$ and $W / l^{5}(\boldsymbol{d})$ mice at $48 \mathrm{~h}$. The arrows point to the endings of individual neurites. SCGs were examined $7 \mathrm{~d}$ ftter transection of the internal and external carotid nerves. Phase micrographs are shown for conditioned SCG explants from WT (g) and WId $(\boldsymbol{h})$ mice after $48 \mathrm{~h}$. In the SCG, no significant difference in neurite outgrowth was seen between the two genotypes $(\boldsymbol{e}, \boldsymbol{f}) .{ }^{*} p<0.05,{ }^{* *} p<0.001$. Scale bars, $100 \mu \mathrm{m}$. 


\section{DRG}
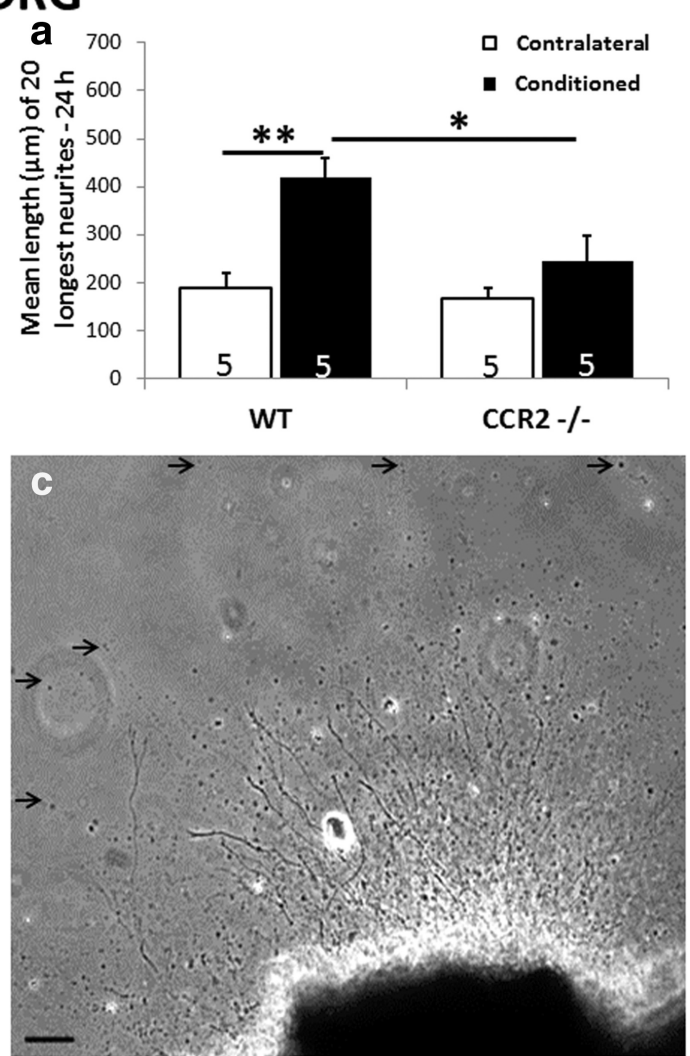

\section{SCG}
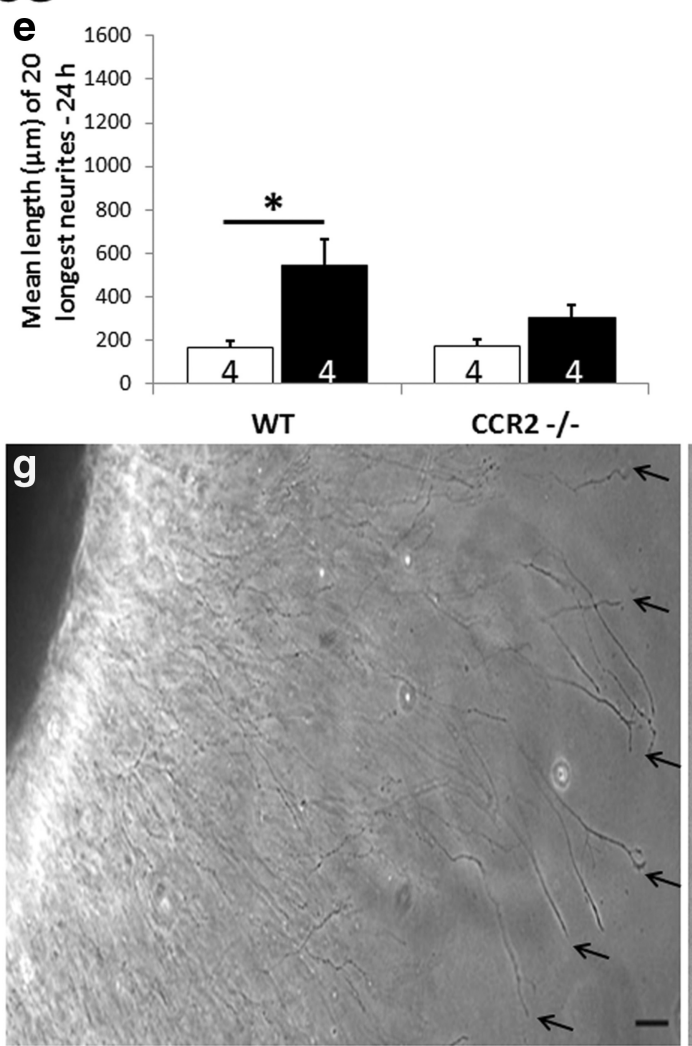
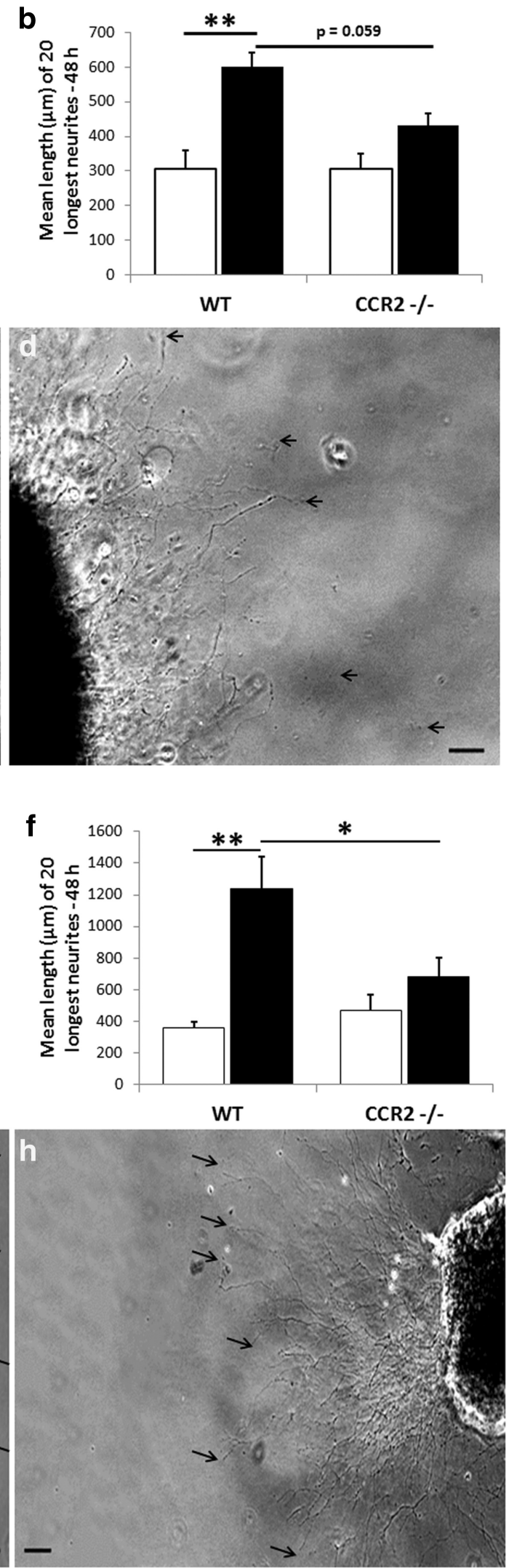

Figure 8. The conditioning lesion effect is abolished in DRG and SCG explants from $C\left(C R 2^{-1-}\right.$ mice. Seven days after unilateral sciatic nerve transection, DRGs were placed in explant culture, and neurite outgrowth was measured after $24 \mathrm{~h}(\boldsymbol{a})$ and $48 \mathrm{~h}(\boldsymbol{b})$. The representative phase micrographs are of individual conditioned DRG explants from WT (c) and $\left(C R 2^{-1-}(\boldsymbol{d})\right.$ mice at $48 \mathrm{~h}$. The arrows point to the endings of individual neurites. Examination of $S C G$ explants from $C\left(R 2^{-/}\right.$mice $7 \mathrm{~d}$ after transection of the internal and external carotid nerves revealed no conditioning lesion effect at $24 \mathrm{~h}(\boldsymbol{e})$ or $48 \mathrm{~h}(\boldsymbol{f})$. Representative micrographs of individual conditioned SCGs are shown for WT $(\boldsymbol{g})$ and CCR2 ${ }^{-1-}(\boldsymbol{h})$ mice at $48 \mathrm{~h} .{ }^{*} p<0.05,{ }^{* *} p<0.001$. Scale bars, 100 $\mu \mathrm{m}$. 

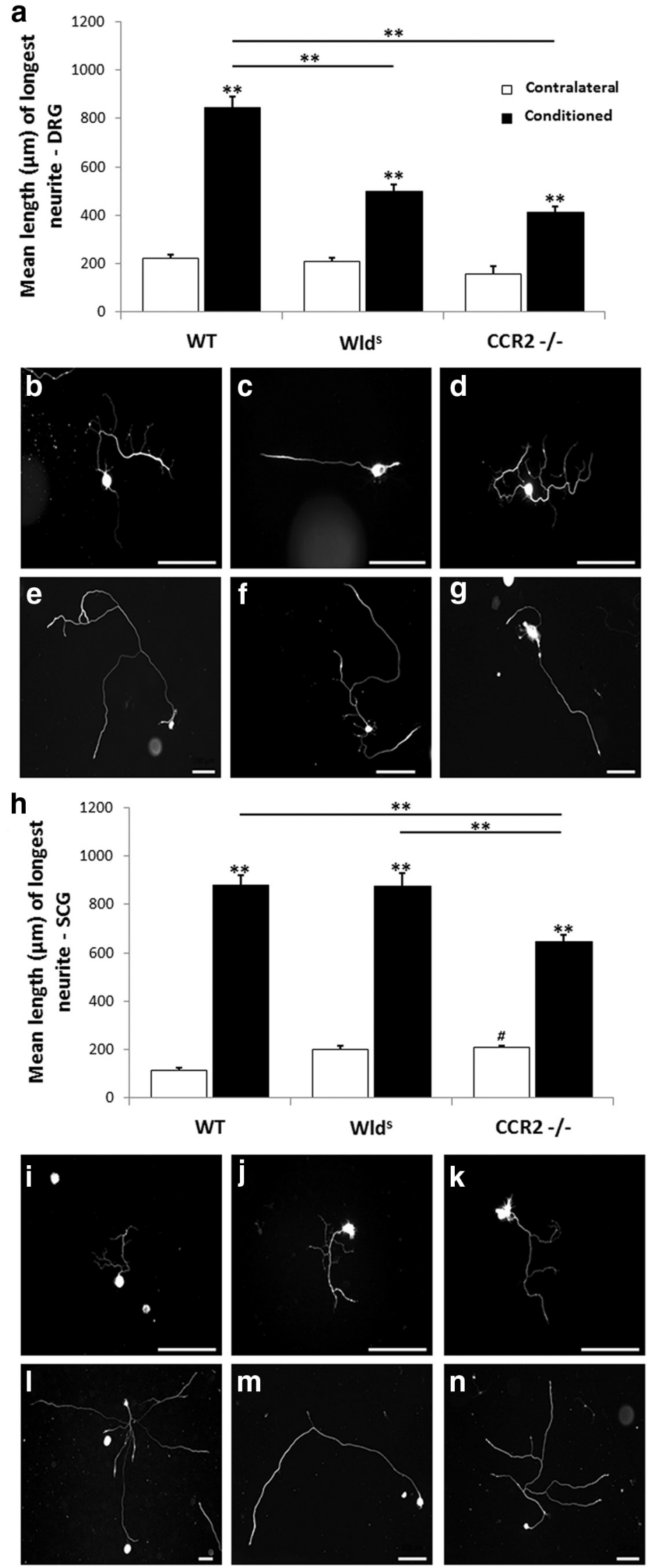

Figure 9. Neurite outgrowth from dissociated cells after $24 \mathrm{~h}$ in culture from DRG $(\boldsymbol{a}-\boldsymbol{g})$ and SCG $(\boldsymbol{h}-\boldsymbol{n})$ neurons. The sciatic nerve and the internal and external carotid nerves were transected unilaterally in WT, WId ${ }^{5}$ and $C\left(R 2^{-1-}\right.$ mice. Seven days later, the DRGs and SCGs were removed, dissociated, and cultured for $24 \mathrm{~h}$. Neurite outgrowth was measured and expressed as mean neurons was the finding that expression of three RAGs (c-JUN, growth-associated protein-43, and the medium neurofilament protein) did not differ between mutant and WT animals (Brown et al., 1994; Gold et al., 1994; Bisby et al., 1995). Of course, these are only three of the hundreds of genes whose expression is altered after axotomy (Costigan et al., 2002; Boeshore et al., 2004). Our finding that the injury-induced upregulation of CCL2 is lessened in the $W l d^{5}$ mouse in sensory and sympathetic neurons is the first demonstration of a change in expression of a RAG in neurons in these mutants.

Our data also strongly suggest that CCL2 acting via CCR2 expressed on monocytes is involved in monocyte entry into peripheral ganglia. However, there are two caveats in interpreting our $C C R 2^{-1-}$ data. First, it is known that CCR2 is involved in the exit of monocytes from the bone marrow (Ingersoll et al., 2011). Therefore, the extent that knocking out this receptor diminishes monocyte entry into the bloodstream and the extent to which it blocks entry from the bloodstream into particular tissues must be resolved with additional experiments. Second, it has been demonstrated that CCR2 receptors are present on DRG neurons in addition to being present on macrophages (White et al., 2009), and, in a single study, CCL2 was shown to promote neurite outgrowth from neurons of the statoacoustic ganglion of the inner ear (Bianchi et al., 2005). Thus, CCL2 might have a direct growth-promoting effect on sensory neurons.

In the $C C R 2^{-/-}$mice, no conditioning lesion effect was seen in either the explanted DRG or SCG. The importance of macrophage action in axotomized ganglia is perhaps most directly demonstrated in these animals in which Wallerian degen-

$\longleftarrow$

length of the longest neurite from each neuron. Greater than 50 neurons were measured for each group, with the exception of the $C_{C R 2^{-1-}}$ sham DRG group in which 21 neurons were measured. A conditioning lesion response was observed in all three genotypes, but in DRGs, the response was significantly less than WT in both mutants $(\boldsymbol{a})$. In SCGs, the magnitude of conditioning lesion response was similar in WId $d^{5}$ and WT mice but was significantly less in $\mathrm{CCR}^{-/-}$mice (h). Representative micrographs of single DRG neurons from contralateral $(\boldsymbol{b}-\boldsymbol{d})$ and conditioned $(\boldsymbol{e}-\boldsymbol{g})$ ganglia from WT $(\boldsymbol{b}, \boldsymbol{e})$, WId $(\boldsymbol{c}, \boldsymbol{f})$, and $C\left(R 2^{-1-}(\boldsymbol{d}, \boldsymbol{g})\right.$ mice. Representative micrographs of single SCG neurons from contralateral $(\boldsymbol{i}-\boldsymbol{k})$ and conditioned $(\boldsymbol{I}-\boldsymbol{n})$ ganglia from WT $(\boldsymbol{i}, \boldsymbol{l}), W I d^{5}(\boldsymbol{j}, \boldsymbol{m})$, and $C\left(R 2^{-/-}(\boldsymbol{k}, \boldsymbol{n})\right.$ mice. ${ }^{* *} p<0.001$. \# indicates that the mean length of $C\left(R 2^{-/-}\right.$ contralateral SCG neurons was significantly longer than WT $(p=0.04)$. Scale bars, $100 \mu \mathrm{m}$. 
eration appears to be similar to that in WT animals. Although all of our outgrowth experiments were designed to minimize any possible inhibition of regeneration produced by the distal nerve stump, we found, in addition and to our surprise, normal Wallerian degeneration in the $C C R 2^{-/-}$mice despite the fact that we found no accumulation of macrophages in the distal nerve. This finding that infiltrating monocytes are not required for normal Wallerian degeneration is contrary to the view presented in two recent reviews (Gaudet et al., 2011; Wang et al., 2012); however, it is supported by a single older study of Perry et al. (1995) in which mice were subjected to whole-body irradiation. Our results also seem in conflict with those reported by Barrette et al. (2008, their Fig. 6), in which the clearance of LFB staining in their thymidine kinase mutants was substantially reduced. Additional studies are required to determine the basis of these differences.

Many questions remain concerning macrophage action within ganglia. For example, we do not know the phenotype of the hematogenous macrophages in these ganglia (e.g., M1 or M2), what these cells might be releasing that stimulates neurite outgrowth, and whether other immune cells participate in this stimulation (Gordon and Martinez, 2010; Gaudet et al., 2011; Gensel et al., 2012; Kurimoto et al., 2013). The growthpromoting effect of lens injury on retinal ganglion cells thought initially to be attributed to macrophages is now thought to be mediated by either neutrophils or astrocytes (Leon et al., 2000; Leibinger et al., 2009; Kurimoto et al., 2013). Another question of interest is whether microglia could play a similar role in the CNS as macrophages do in the PNS, a possibility raised by the recent findings of Shokouhi et al. (2010).

In summary, our study involves four key findings. First, it is highly likely that CCL2/CCR2 signaling is important in the infiltration of monocytes into peripheral ganglia after axotomy. Second, the decreased sensory nerve regeneration seen by others in $W l d^{s}$ mice involves both a decrease in the growth response of the neurons, as well as probably the long-hypothesized influence of extrinsic factors. Third, Wallerian degeneration can proceed in the absence of infiltrating monocytes. Fourth, macrophage accumulation in peripheral ganglia after injury plays an essential role in the response of neurons to a conditioning lesion. Together, these findings establish an important new site of macrophage action in promoting nerve regeneration.

\section{References}

Abbadie C, Lindia JA, Cumiskey AM, Peterson LB, Mudgett JS, Bayne EK, DeMartino JA, MacIntyre DE, Forrest MJ (2003) Impaired neuropathic pain responses in mice lacking the chemokine receptor CCR2. Proc Natl Acad Sci U S A 100:7947-7952. CrossRef Medline

Agius E, Cochard P (1998) Comparison of neurite outgrowth induced by intact and injured sciatic nerves: a confocal and functional analysis. J Neurosci 18:328-338. Medline

Barrette B, Hébert MA, Filali M, Lafortune K, Vallières N, Gowing G, Julien JP, Lacroix S (2008) Requirement of myeloid cells for axon regeneration. J Neurosci 28:9363-9376. CrossRef Medline

Barrette B, Calvo E, Vallières N, Lacroix S (2010) Transcriptional profiling of the injured sciatic nerve of mice carrying the Wld(S) mutant gene: identification of genes involved in neuroprotection, neuroinflammation, and nerve regeneration. Brain Behav Immun 24:1254-1267. CrossRef Medline

Bedi KS, Winter J, Berry M, Cohen J (1992) Adult rat dorsal root ganglion neurons extend neurites on predegenerated but not on normal peripheral nerves in vitro. Eur J Neurosci 4:193-200. CrossRef Medline

Beuche W, Friede RL (1984) The role of non-resident cells in Wallerian degeneration. J Neurocytol 13:767-796. CrossRef Medline

Bianchi LM, Daruwalla Z, Roth TM, Attia NP, Lukacs NW, Richards AL, White IO, Allen SJ, Barald KF (2005) Immortalized mouse inner ear cell lines demonstrate a role for chemokines in promoting the growth of developing statoacoustic ganglion neurons. J Assoc Res Otolaryngol 6:355-367. CrossRef Medline

Bisby MA, Chen S (1990) Delayed wallerian degeneration in sciatic nerves of C57BL/Ola mice is associated with impaired regeneration of sensory axons. Brain Res 530:117-120. CrossRef Medline

Bisby MA, Tetzlaff W, Brown MC (1995) Cell body response to injury in motoneurons and primary sensory neurons of a mutant mouse, Ola (Wld), in which Wallerian degeneration is delayed. J Comp Neurol 359: 653-662. CrossRef Medline

Boeshore KL, Schreiber RC, Vaccariello SA, Sachs HH, Salazar R, Lee J, Ratan RR, Leahy P, Zigmond RE (2004) Novel changes in gene expression following axotomy of a sympathetic ganglion: a microarray analysis. J Neurobiol 59:216-235. CrossRef Medline

Brown MC, Lunn ER, Perry VH (1991a) Poor growth of mammalian motor and sensory axons into intact proximal nerve stumps. Eur J Neurosci 3:1366-1369. CrossRef Medline

Brown MC, Perry VH, Lunn ER, Gordon S, Heumann R (1991b) Macrophage dependence of peripheral sensory nerve regeneration: possible involvement of nerve growth factor. Neuron 6:359-370. CrossRef Medline

Brown MC, Perry VH, Hunt SP, Lapper SR (1994) Further studies on motor and sensory nerve regeneration in mice with delayed Wallerian degeneration. Eur J Neurosci 6:420-428. CrossRef Medline

Brück W (1997) The role of macrophages in Wallerian degeneration. Brain Pathol 7:741-752. CrossRef Medline

Chen S, Bisby MA (1993) Impaired motor axon regeneration in the C57BL/ Ola mouse. J Comp Neurol 333:449-454. CrossRef Medline

Chong MS, Woolf CJ, Haque NS, Anderson PN (1999) Axonal regeneration from injured dorsal roots into the spinal cord of adult rats. J Comp Neurol 410:42-54. CrossRef Medline

Costigan M, Befort K, Karchewski L, Griffin RS, D’Urso D, Allchorne A, Sitarski J, Mannion JW, Pratt RE, Woolf CJ (2002) Replicate highdensity rat genome oligonucleotide microarrays reveal hundreds of regulated genes in the dorsal root ganglion after peripheral nerve injury. BMC Neurosci 3:16. CrossRef Medline

Dailey AT, Avellino AM, Benthem L, Silver J, Kliot M (1998) Complement depletion reduces macrophage infiltration and activation during Wallerian degeneration and axonal regeneration. J Neurosci 18:6713-6722. Medline

Deshmane SL, Kremlev S, Amini S, Sawaya BE (2009) Monocyte chemoattractant protein-1 (MCP-1): an overview. J Interferon Cytokine Res 29: 313-326. CrossRef Medline

Edström A, Ekström PA, Tonge D (1996) Axonal outgrowth and neuronal apoptosis in cultured adult mouse dorsal root ganglion preparations: effects of neurotrophins, of inhibition of neurotrophin actions and of prior axotomy. Neuroscience 75:1165-1174. CrossRef Medline

Ekström PA, Mayer U, Panjwani A, Pountney D, Pizzey J, Tonge DA (2003) Involvement of alpha7betal integrin in the conditioning-lesion effect on sensory axon regeneration. Mol Cell Neurosci 22:383-395. CrossRef Medline

Flett DL, Bell C (1991) Topography of functional subpopulations of neurons in the superior cervical ganglion of the rat. J Anat 177:55-66. Medline

Gaudet AD, Popovich PG, Ramer MS (2011) Wallerian degeneration: gaining perspective on inflammatory events after peripheral nerve injury. J Neuroinflammation 8:110. CrossRef Medline

Gavazzi I, Kumar RD, McMahon SB, Cohen J (1999) Growth responses of different subpopulations of adult sensory neurons to neurotrophic factors in vitro. Eur J Neurosci 11:3405-3414. CrossRef Medline

Gensel JC, Kigerl KA, Mandrekar-Colucci SS, Gaudet AD, Popovich PG (2012) Achieving CNS axon regeneration by manipulating convergent neuro-immune signaling. Cell Tissue Res 349:201-213. CrossRef Medline

Gold BG, Austin DR, Storm-Dickerson T (1994) Multiple signals underlie the axotomy-induced up-regulation of c-JUN in adult sensory neurons. Neurosci Lett 176:123-127. CrossRef Medline

Gordon S, Martinez FO (2010) Alternative activation of macrophages: mechanism and functions. Immunity 32:593-604. CrossRef Medline

Habecker BA, Sachs HH, Rohrer H, Zigmond RE (2009) The dependence on gp130 cytokines of axotomy induced neuropeptide expression in adult sympathetic neurons. Dev Neurobiol 69:392-400. CrossRef Medline

Hall SM (1993) Observations on the progress of Wallerian degeneration in transected peripheral nerves of C57BL/Wld mice in the presence of recruited macrophages. J Neurocytol 22:480-490. CrossRef Medline 
Hu-Tsai M, Winter J, Emson PC, Woolf CJ (1994) Neurite outgrowth and GAP-43 mRNA expression in cultured adult rat dorsal root ganglion neurons: effects of NGF or prior peripheral axotomy. J Neurosci Res 39:634-645. CrossRef Medline

Hyatt Sachs H, Rohrer H, Zigmond RE (2010) The conditioning lesion effect on sympathetic neurite outgrowth is dependent on gp130 cytokines. Exp Neurol 223:516-522. CrossRef Medline

Ingersoll MA, Platt AM, Potteaux S, Randolph GJ (2011) Monocyte trafficking in acute and chronic inflammation. Trends Immunol 32:470-477. CrossRef Medline

Joseph BS (1973) Somatofugal events in Wallerian degeneration: a conceptual overview. Brain Res 59:1-18. CrossRef Medline

Kurimoto T, Yin Y, Habboub G, Gilbert HY, Li Y, Nakao S, HafeziMoghadam A, Benowitz LI (2013) Neutrophils express oncomodulin and promote optic nerve regeneration. J Neurosci 33:14816-14824. CrossRef Medline

Langley JN, Anderson HK (1904) The union of different kinds of nerve fibres. J Physiol 31:365-391. Medline

Leibinger M, Müller A, Andreadaki A, Hauk TG, Kirsch M, Fischer D (2009) Neuroprotective and axon growth-promoting effects following inflammatory stimulation on mature retinal ganglion cells in mice depend on ciliary neurotrophic factor and leukemia inhibitory factor. J Neurosci 29:14334-14341. CrossRef Medline

Leon S, Yin Y, Nguyen J, Irwin N, Benowitz LI (2000) Lens injury stimulates axon regeneration in the mature rat optic nerve. J Neurosci 20:46154626. Medline

Lu X, Richardson PM (1991) Inflammation near the nerve cell body enhances axonal regeneration. J Neurosci 11:972-978. Medline

Lu X, Richardson PM (1993) Responses of macrophages in rat dorsal root ganglia following peripheral nerve injury. J Neurocytol 22:334-341. CrossRef Medline

Luk HW, Noble LJ, Werb Z (2003) Macrophages contribute to the maintenance of stable regenerating neurites following peripheral nerve injury. J Neurosci Res 73:644-658. CrossRef Medline

Lunn ER, Perry VH, Brown MC, Rosen H, Gordon S (1989) Absence of Wallerian degeneration does not hinder regeneration in peripheral nerve. Eur J Neurosci 1:27-33. CrossRef Medline

McQuarrie IG, Grafstein B (1973) Axon outgrowth enhanced by a previous nerve injury. Arch Neurol 29:53-55. CrossRef Medline

Nadeau S, Filali M, Zhang J, Kerr BJ, Rivest S, Soulet D, Iwakura Y, de Rivero Vaccari JP, Keane RW, Lacroix S (2011) Functional recovery after peripheral nerve injury is dependent on the pro-inflammatory cytokines IL-1beta and TNF: implications for neuropathic pain. J Neurosci 31: 12533-12542. CrossRef Medline

Neumann S, Woolf CJ (1999) Regeneration of dorsal column fibers into and beyond the lesion site following adult spinal cord injury. Neuron 23:83-91. CrossRef Medline

Oldfors A (1980) Macrophages in peripheral nerves. An ultrastructural and enzyme histochemical study on rats. Acta Neuropathol 49:43-49. CrossRef Medline

Perrin FE, Lacroix S, Avilés-Trigueros M, David S (2005) Involvement of monocyte chemoattractant protein-1, macrophage inflammatory protein-1alpha and interleukin-1beta in Wallerian degeneration. Brain 128:854-866. CrossRef Medline

Perry VH (1994) Macrophages and the nervous system. Austin, TX: Landes.

Perry VH, Brown MC (1992) Role of macrophages in peripheral nerve degeneration and repair. Bioessays 14:401-406. CrossRef Medline

Perry VH, Tsao JW, Fearn S, Brown MC (1995) Radiation-induced re- ductions in macrophage recruitment have only slight effects on myelin degeneration in sectioned peripheral nerves of mice. Eur J Neurosci 7:271-280. CrossRef Medline

Richardson PM, Verge VM (1987) Axonal regeneration in dorsal spinal roots is accelerated by peripheral axonal transection. Brain Res 411:406408. CrossRef Medline

Rotshenker S (2011) Wallerian degeneration: the innate-immune response to traumatic nerve injury. J Neuroinflammation 8:109. CrossRef Medline

Sachs HH, Wynick D, Zigmond RE (2007) Galanin plays a role in the conditioning lesion effect in sensory neurons. Neuroreport 18:1729-1733. CrossRef Medline

Salegio EA, Pollard AN, Smith M, Zhou XF (2011) Macrophage presence is essential for the regeneration of ascending afferent fibres following a conditioning sciatic nerve lesion in adult rats. BMC Neurosci 12:11. CrossRef Medline

Schreiber RC, Shadiack AM, Bennett TA, Sedwick CE, Zigmond RE (1995) Changes in the macrophage population of the rat superior cervical ganglion after postganglionic nerve injury. J Neurobiol 27:141-153. CrossRef Medline

Schreiber RC, Krivacic K, Kirby B, Vaccariello SA, Wei T, Ransohoff RM, Zigmond RE (2001) Monocyte chemoattractant protein (MCP)-1 is rapidly expressed by sympathetic ganglion neurons following axonal injury. Neuroreport 12:601-606. CrossRef Medline

Shoemaker SE, Sachs HH, Vaccariello SA, Zigmond RE (2005) A conditioning lesion enhances sympathetic neurite outgrowth. Exp Neurol 194:432443. CrossRef Medline

Shokouhi BN, Wong BZ, Siddiqui S, Lieberman AR, Campbell G, Tohyama $\mathrm{K}$, Anderson PN (2010) Microglial responses around intrinsic CNS neurons are correlated with axonal regeneration. BMC Neurosci 11:13. CrossRef Medline

Siebert H, Sachse A, Kuziel WA, Maeda N, Brück W (2000) The chemokine receptor CCR2 is involved in macrophage recruitment to the injured peripheral nervous system. J Neuroimmunol 110:177-185. CrossRef Medline

Sommer C, Schäfers M (1998) Painful mononeuropathy in C57BL/Wld mice with delayed wallerian degeneration: differential effects of cytokine production and nerve regeneration on thermal and mechanical hypersensitivity. Brain Res 784:154-162. CrossRef Medline

Surmi BK, Hasty AH (2010) The role of chemokines in recruitment of immune cells to the artery wall and adipose tissue. Vascul Pharmacol 52:2736. CrossRef Medline

Tanaka T, Minami M, Nakagawa T, Satoh M (2004) Enhanced production of monocyte chemoattractant protein-1 in the dorsal root ganglia in a rat model of neuropathic pain: possible involvement in the development of neuropathic pain. Neurosci Res 48:463-469. CrossRef Medline

Vargas ME, Watanabe J, Singh SJ, Robinson WH, Barres BA (2010) Endogenous antibodies promote rapid myelin clearance and effective axon regeneration after nerve injury. Proc Natl Acad Sci U S A 107:11993-11998. CrossRef Medline

Wang JT, Medress ZA, Barres BA (2012) Axon degeneration: Molecular mechanisms of a self-destruction pathway. J Cell Biol 196:7-18. CrossRef Medline

White DM, Mansfield K, Kelleher K (1996) Increased neurite outgrowth of cultured rat dorsal root ganglion cells following transection or inhibition of axonal transport of the sciatic nerve. Neurosci Lett 208:93-96. CrossRef Medline

White FA, Feldman P, Miller RJ (2009) Chemokine signaling and the management of neuropathic pain. Mol Interv 9:188-195. CrossRef Medline 